\title{
Serum levels of oxidative stress marker malondialdehyde in breast cancer patients in relation to pathohistological factors, estrogen receptors, menopausal status, and age
}

Jasmina Gradaščević-Gubaljevićc ${ }^{*}$, Nahida Srabović , Adlija Jevrić-Čauševićc , Adaleta Softić Adi Rifatbegović ${ }^{4}$, Jasminka Mujanović-Mustedanagićs , Esmeralda Dautovićc , Aida Smajlović Zlata Mujagić

1PZU Mediflor, Zivinice, Bosnia and Herzegovina, '2Department of Biochemistry, Faculty of Pharmacy, University of Tuzla, Tuzla, Bosnia and Herzegovina, ${ }^{3}$ Department of Biochemistry and Clinical Analyses, Faculty of Pharmacy, University of Sarajevo, Bosnia and Herzegovina, ${ }^{4}$ Clinic for Surgery, University Clinical Centre of Tuzla, Tuzla, Bosnia and Herzegovina, ${ }^{5}$ Polyclinic for Laboratory Diagnostic, University Clinical Centre of Tuzla, Tuzla, Bosnia and Herzegovina

\begin{abstract}
Introduction: The aim of this study was to determine the serum levels of malondialdehyde (MDA) in patients with invasive breast cancer in relation to its serum levels in patients with benign breast disease, and to investigate correlation between MDA serum levels with pathohistological prognostic factors (tumor size, lymph node involvement, and histologic grade [HG]), estrogen receptor (ER) status, and with breast cancer patient's age and menopausal status.

Methods: A total of 43 with well-documented invasive breast cancer were included in this study: 27 with positive axillary's lymph nodes, and 16 with negative axillary's lymph nodes, and 39 patients with findings of benign breast diseases. MDA determination in serum of breast cancer and benign breast disease patients was performed by the fluorimetric method, immunohistochemical staining was performed for ER, and routine pathohistological examination was conducted for pathohistological factors.

Results: MDA serum levels in breast cancer patients were significantly higher than MDA serum levels in benign breast disease patients $(p=0.042)$. No statistically significant difference between MDA serum levels in breast cancer patients with and without lymph node metastases was found $(p=0.238)$. No statistically significant correlations between MDA serum levels and tumor size $(p=0.256), \mathrm{HG}(p=0.124)$, or number of positive lymph nodes (0.113) were found. A statistically significant correlation between serum MDA levels and ages of breast cancer patients with lymph node metastases was found $(p=0.006)$.
\end{abstract}

Conclusion: Obtained results support the importance of MDA in the carcinogenesis of breast cancer. According to our findings, serum level of MDA could not be a useful prognostic factor in breast cancer.

Key words: Breast cancer; benign breast disease; oxidative stress; malondialdehyde; pathohistological factors; estrogen receptors

\footnotetext{
*Corresponding author: J. Gradaščević-Gubaljević, PZU Mediflor, Zivinice, Bosnia and Herzegovina,

E-mail: jasmina.gubaljevic@gmail.com
}

Submitted: 14 September 2018/Accepted: 20 November 2018

DOI: https://doi.org/10.17532/jhsci.2018.263

UNIVERSITY OF SARAJEVO FACULTY OF HEALTH STUDIES

\section{INTRODUCTION}

Breast cancer is the most common cancer in women (1), accounting for $25 \%$ of all female cancers worldwide (2). Etiology of breast cancer is multifactorial which includes genetic, environmental, 
social, demographic, and hormonal factors (3). Most of the risk factors for breast cancer development and progression are to some extent implicated with reactive species (RS) generation $(4,5)$. Breast tumors are embedded in very pro-oxidative environment, as the mammary gland is plenty in surrounding adipose tissue. Therefore, the exceeding RS acts on the lipid neighborhood yielding several active metabolites that can regulate a wide range of cellular processes (6-8). Some of the consequences of carcinoma cell oxidative stress are: Accelerated tumor progression due to RS mediated inactivation of additional tumor suppressor genes within tumor cells and increasing expression of proto-oncogenes (9-11), activation of growth-promoting signaling pathways due to RS mediated promotion of cell proliferation in vitro (12), increasing blood supply to tumor cells (13), and consequently increasing risk of metastasis (14). In addition, oxygen radicals may augment tumor cells migration, increasing the risk of invasion and metastasis (14).

Several markers of the oxidative stress in patients with breast cancer are currently available. One of the most important of these is malondialdehyde (MDA), low-molecular-weight aldehydes derived from lipid peroxidation processes, which has been used as a marker of lipid peroxidation (15).

Various studies were conducted with the relation of oxidative stress and human breast cancer. Nevertheless, previous studies regarding pathohistological factors are poorly understood. The aim of this study was to determine the serum levels of MDA in patients with invasive breast cancer in relation to its serum levels in patients with benign breast disease, and to investigate correlation between MDA serum levels with pathohistologic prognostic factors such as tumor size, lymph node involvement, histologic grade (HG), estrogen receptor (ER) status, and with breast cancer patient's age and menopausal status.

\section{METHODS}

\section{Patients}

This study was approved by the Ethic Committee of the University Clinical Centre Tuzla. Informed consent was obtained from all of the patients. It was a prospective case-control study with well-defined including criteria: Histologically proven invasive breast cancer, no distant metastases, no previous adjuvant therapy, currently under no treatment, and no other major illnesses.

According to the PHD findings, a total of 43 with well documented invasive breast cancer were included in this study: 27 with positive axillary's lymph nodes, 16 with negative axillary's lymph nodes, and 39 patients with findings of benign breast diseases were also included in the study. All patients were subjected to the appropriate breast surgery at the Department of Surgery, University Clinical Centre of Tuzla (all of them were females, Caucasians, residents of narrow region in Tuzla surrounding, Bosnia and Herzegovina). Tumor tissue and serum sample from patients with primary invasive breast cancer were used, as well as breast tissue and serum samples from patients with benign breast disease.

Routine pathological examination was performed with hematoxylin-eosin staining. Tumors were classified according to the criteria of the World Health Organization (16). Histological grade was obtained in accordance with a modified Scarff-BloomRichardson histological grading system. The staging was based on tumor-node-metastasis (TNM) system. Tumor size was evaluated separately $(0.5-$ $1.0 \mathrm{~cm}, \leq 2 \mathrm{~cm}, 2-5 \mathrm{~cm},>5 \mathrm{~cm}$ ).

Blood samples for MDA level determination were collected at the Department of Surgery, University Clinical Centre. Venous blood samples were obtained $24 \mathrm{~h}$ before surgery by venepuncture $(7 \mathrm{~mL}$ of blood for analysis from each patient). After $1 / 2 \mathrm{~h}$, samples were processed at room temperature by centrifuging at $3000 \mathrm{rpm}$ for $10 \mathrm{~min}$. Serum samples were stored in plastic microtubes $(0.5 \mathrm{~mL} / \mathrm{micro}-$ tube) in the freezer at $-80^{\circ} \mathrm{C}$. Extracting and sample storing were carried out in Polyclinic for Laboratory Diagnostic, University Clinical Centre Tuzla.

\section{Immunohistochemistry}

Immunohistochemical staining for ER was performed on $4 \mu \mathrm{m}$ thick formalin-fixed paraffin embedded sections. Deparaffinization and rehydration were performed in xylene and ethanol solutions (reducing concentration 96-70\%). Sections were incubated in $\mathrm{H}_{2} \mathrm{O}_{2}$ solution $\left(1.5 \% \mathrm{H}_{2} \mathrm{O}_{2}\right.$ in methanol) for $15 \mathrm{~min}$ to block endogenous peroxidases. 
Antigen retrieval was performed in procedure with the retrieval buffer $(\mathrm{pH}=9.0$, TRIS $20 \mathrm{mmol} / \mathrm{L}$, EDTA $0.05 \mathrm{mmol} / \mathrm{L}, 0.05 \%$ Tween 20 ) in a microwave oven by heating the slides for $15 \mathrm{~min}$. After rinsing with the phosphate buffered saline (PBS) buffer $\left(100 \mathrm{mmol} / \mathrm{L} \mathrm{NaCl}\right.$ and $6 \mathrm{mmol} / \mathrm{L} \mathrm{Na}_{2} \mathrm{HPO}_{4}$ $\times 2 \mathrm{H}_{2} \mathrm{O}$ ), normal goat serum (Dako, Golstrup, Denmark) was applied for 15 min to block non-specific antibody binding. Subsequently, sections were incubated with primary antibody (a mouse anti-human monoclonal antibody against ER, clone NCLER-6F11, Newcastle Upon Tyne, UK, 1: 50 diluted in $\mathrm{PBS} /$ Bovine serum albumin buffer, $\mathrm{pH}=7.2$ ) at $37^{\circ} \mathrm{C}$. A three-step technique was used for visualization with biotin-conjugated secondary antibody (Dako, Golstrup, Denmark) and diaminobenzidine (Fluka Chemie, GmbH, Buchs, Switzerland). Slides were preserved with Canada balsam (turpentine).

\section{Immunohistochemical evaluation}

The evaluation of the immunohistochemical staining for ER was performed by pathologist through a light microscopic observation (Olympus BX-50 light microscope, Olympus Medical System Corp, Tokyo, Japan). The evaluation was performed using Remmeles immunoreactivity score (17) for immunoreactivity analyzing.

\section{MDA determination}

MDA determination in serum of breast cancer and benign breast disease patients was performed by the fluorimetric method $(18,19)$. MDA reacts with thiobarbituric acid (TBA) in an acid medium to form a fluorescent complex that is extracted with butanol and measured by fluorescence (20-23). Fluorescence spectra of MDA-TBA fluorescent complex were recorded at spectrofluorimeter RF-5301 PC (Shimadzu, Japan). Fluorescence emission was recorded at $530 \mathrm{~nm}$ after excitation $516 \mathrm{~nm}$. The entrance and exit slits for the excitation light beam were both $1.5 \mathrm{~nm}$. Sample and standard preparation was performed using Ohkawa's modified Yagi's method (20-24).

\section{Statistical analysis}

The results were evaluated by Mann-Whitney $U$-test for independent samples and with Spearman's correlation. For all performed tests, $p<0.05$ was considered as statistically significant. For statistical analyses, we used SPSS 17.0 software (SPSS Inc., USA).

\section{RESULTS}

MDA levels were determined in 43 patients with breast cancer and 39 patients with benign breast disease, which is considered as a control group. MDA serum levels in breast cancer patients were significantly higher than MDA serum levels in benign breast disease patients $(p=0.042)$ (Table 1). No statistically significant difference between MDA serum levels in breast cancer patients with and without lymph node metastases was found $(p=0.238)$ (Table 2). Pathohistological factors (tumor size, histological grade, and number of positive lymph nodes) were determined in all breast cancer patients, and according to the

TABLE 1. MDA serum levels in patients with breast cancer and with benign breast disease

\begin{tabular}{lcc}
\hline Group & Number & MDA levels Mean \pm SD error. Min-Max [nmol/mL] \\
\hline 1. Patients with breast cancer & 43 & $29.09 \pm 19.32[5.04-95.14]$ \\
2. Patients with benign breast disease & 39 & $21.38 \pm 15.01[5.34-65.17]$ \\
\hline
\end{tabular}

Differences in MDA serum levels between breast cancer and benign breast disease patients Mann-Whitney $\mathrm{U}=619,00 ; P=0.042^{*}$, MDA: Malondialdehyde

TABLE 2. MDA serum levels in breast cancer patients with and without lymph node metastases

\begin{tabular}{lcc}
\hline Group & Number & MDA levels Mean \pm SD error. Min-Max [nmol/mL] \\
\hline 1. Patients with lymph node metastases & 27 & $30.77 \pm 17.83[5.04-63.42]$ \\
2. Patients without lymph node metastases & 16 & $26.26 \pm 21.92[5.38-95.14]$ \\
\hline
\end{tabular}

Differences in MDA serum levels between breast cancer and benign breast disease patients Mann-Whitney $U=169,00 ; P=0.238$, MDA: Malondialdehyde 
results, the pathological TNM status was obtained (Table 3). In breast cancer patients, no statistically significant correlations between MDA serum levels and tumor size $(p=0.256)$, HG $(p=0.124)$ or number of positive lymph nodes (0.113) in breast cancer patients with lymph node metastases were found. A statistically significant difference in MDA serum levels between ER-positive and ER-negative breast cancer patients was not found $(p=0.726)$ (Table 4). Regarding menopausal status, breast cancer patients were classified into two groups, breast cancer patients with premenopausal status and with postmenopausal status (Table 5). No statistically significant difference in the serum level of MDA between these groups was found ( $p$ $=0.130)$. Regarding ages of breast cancer patients, no significant correlation between serum MDA levels and ages of patients was found, but statistically significant correlation between serum MDA levels and ages of breast cancer patients with lymph node metastases was found $(p=0.006)$ (Figure 1).

\section{DISCUSSION}

Increased MDA levels have been reported in breast, ovarian cancer, gastric and lung cancer, and colorectal adenomas (25-30). MDA, as low molecular weight aldehyde, can be produced from the free radical attack on polyunsaturated fatty acids. The process of lipid peroxidation is one of the oxidative conversions of polyunsaturated fatty acids to MDA, the main sensitive parameter of lipid peroxidation (15). Increased MDA levels have been reported in breast, ovarian cancer, gastric and lung cancer, and colorectal adenomas (25-30). Several studies present evidence that reactive oxygen species (ROS) are involved in the etiology and progression of breast cancer (31). Results in this study showed an increase in MDA serum level in invasive breast cancer patients as compared to MDA serum level in benign breast disease patients (Table 1). Previous studies report increased plasma levels of MDA in breast cancer patients compared to healthy control (26), as well as higher MDA concentration in malignant tissue when compared to normal tissue samples from healthy controls $(32,33)$. Thus, previous findings and our results suggest that oxidative stress is present not only in cancer cells but also in the whole organism affected by the tumor. Furthermore, there was found a trend toward increased MDA levels in malignant breast cancer tissue as the TNM stage increases (32). Qebesy et al. found negative relationship between the tissue level of MDA and HG in breast cancer patients suggesting that the defect in the antioxidant mechanism may contribute to tumor development and progression (33) regarding that HG is considered a highly valuable prognostic factor for breast cancer as poorly differentiated lesions are associated with significantly poor clinical outcome (34). In this study, we have not found a significant correlation between MDA level and HG, as well as between MDA level and tumor size and axillary lymph node involvement, which are also considered as a very important prognostic indicator (35). Differences in MDA level between breast cancer patients with positive and negative lymph nodes were tested in this study, since the presence or absence of axillary lymph node involvement is considered as the most significant prognostic indicator for patients with early-stage breast cancer (35) and that there is a direct relationship between the number of involved axillary nodes and the risk for distant recurrence (36). Although in vitro studies have shown that oxidative stress significantly motivate the migratory potential of poorly invasive breast cancer cells MCF-7 through Erk signaling activation (37), we have not found significant difference in MDA levels between patients with positive and with negative lymph nodes (Table 2), nor statistically significant correlation between MDA serum level and number of positive lymph nodes in breast cancer patients.

Estrogen and progesterone receptors are a powerful predictive factor for the likelihood of benefit from adjuvant tamoxifen (35), but the prognostic significance of hormone receptors may not persist long-term (38). A few previous studies have shown the relationship between oxidative stress and estrogen-dependent breast cancer (39-42). It was reported that oxidative stress induces activation of $\mathrm{Akt} / \mathrm{PI} 3 \mathrm{~K} / \mathrm{mTOR}$ signaling, promoting oncogenesis, and tumor progression in estrogen-dependent breast cancer $(39,40)$. Furthermore, multivariate analysis showed that ROS were predictive for TNM status in patients with estrogen-dependent breast cancer (41). In vitro estrogen exposure 
TABLE 3. pTNM status, HG, ER status, ages and MDA serum levels in breast cancer patients

\begin{tabular}{|c|c|c|c|c|}
\hline MDA [nmol/mL] & pTNM & $\mathrm{HG}$ & ER & Ages (years) \\
\hline 8.83 & pT1cN0 & II & + & 60 \\
\hline 24.21 & pT1cN0 & III & + & 63 \\
\hline 23.27 & pT2N3a & III & - & 49 \\
\hline 26.93 & $\mathrm{pT} 2 \mathrm{~N} 1 \mathrm{a}$ & III & + & 42 \\
\hline 12.74 & pT2(s) N0 & ॥ & + & 42 \\
\hline 24.34 & pT4bN1 & ॥ & + & missing data \\
\hline 56.42 & pT3N3a & III & + & 25 \\
\hline 8.61 & pT2NO & I & - & 34 \\
\hline 51.93 & pT1aN0 & III & - & 60 \\
\hline 14.78 & pT3NO & $\|$ & missing data & 60 \\
\hline 32.74 & pT2NO & $\|$ & + & 41 \\
\hline 54.18 & $\mathrm{pT} 2(\mathrm{~m}) \mathrm{N} 3$ & $\|$ & + & 55 \\
\hline 95.14 & pT1N0 & ॥ & - & 72 \\
\hline 63.42 & pT2N2 & ॥ & missing data & 70 \\
\hline 51.44 & pT2N1 & ॥ & + & 62 \\
\hline 5.04 & pT2N3 & III & + & 73 \\
\hline 5.38 & pT2N0 & $\|$ & + & 79 \\
\hline 34.82 & pTa1N0 & $\|$ & + & 58 \\
\hline 20.04 & pT1cN1 & III & missing data & 79 \\
\hline 19.29 & pT2N2a NG3 & ॥ & - & 60 \\
\hline 44.9 & pT4bN1a & III & + & 60 \\
\hline 54.26 & pT2N1a & $\|$ & + & 49 \\
\hline 18.52 & pT2N2a & III & + & 48 \\
\hline 21.3 & pT4dN2a & III & - & 60 \\
\hline 32.78 & pT2N2 & III & - & 49 \\
\hline 16.82 & $\mathrm{pT} 1 \mathrm{a}(\mathrm{s})$ No & ॥ & + & 61 \\
\hline 14.64 & pT3N2a & III & + & 60 \\
\hline 32.41 & pT1bN0 & ॥ & + & 67 \\
\hline 27.82 & pT2N2 & ॥ & + & 58 \\
\hline 11.51 & pT2N1a & ॥ & + & 62 \\
\hline 28.13 & pT2N3 & III & + & 45 \\
\hline 15.36 & pT1cN0 & ॥ & + & 72 \\
\hline 15.33 & pT2N1a & ॥ & + & 57 \\
\hline 55.28 & pT3N2a & ॥ & + & 47 \\
\hline 62.52 & pT2N3 & III & + & 45 \\
\hline 35.45 & pT2N1a & $\|$ & + & 45 \\
\hline 19.78 & pT2mNO & ॥ & + & 60 \\
\hline 9.46 & pT2N1 & III & + & 69 \\
\hline 19.61 & $\mathrm{pT} 1 \mathrm{c}(\mathrm{m}) \mathrm{N} 2$ & ॥ & + & 66 \\
\hline 25.82 & pT2NO & ॥ & + & 35 \\
\hline 10.24 & pT2N2 & $\|$ & + & 70 \\
\hline 24.8 & pT2N2 & ॥ & - & 82 \\
\hline 20.74 & pT2NO & III & - & 61 \\
\hline
\end{tabular}

pTNM: Pathological tumor-node-metastasis, HG: Histologic grade, ER: Estrogen receptor, MDA: Malondialdehyde 
TABLE 4. MDA serum levels in breast cancer patients with positive and negative ERs

\begin{tabular}{lcc}
\hline Group & $\mathrm{N}$ & MDA levels Mean \pm SD error. Min-Max [nmol/mL] \\
\hline 1. ER-positive breast cancer patients & 31 & $28.034 \pm 17.447$ [5.04-63.42] \\
2. ER-negative breast cancer patients & 9 & $33.095 \pm 26.104[8.61-95.14]$ \\
\hline
\end{tabular}

Differences in MDA serum levels between ER-positive and ER-negative breast cancer Mann-Whitney $\mathrm{U}=128,00 ; P=0.726$,

ER: Estrogen receptor, MDA: Malondialdehyde

TABLE 5. MDA serum levels in breast cancer patients regarding menopausal status

\begin{tabular}{lccc}
\hline Group & N & $\begin{array}{c}\text { Ages Mean } \pm S D \\
\text { (years) }\end{array}$ & $\begin{array}{c}\text { MDA levels Mean } \pm S D . \\
\text { error. Min-Max [nmol/mL] }\end{array}$ \\
\hline 1. Breast cancer patients with premenopausal status & 14 & $64.35 \pm 7.27$ & $26.812 \pm 20.203[5.04-95.14]$ \\
2.Breast cancer patients with postmenopausal status & 28 & $45.37 \pm 6.98$ & $33.819 \pm 17.067[8.61-62.52]$ \\
\hline
\end{tabular}

Differences in MDA serum levels between breast cancer patients with premenopausal status and with postmenopausal status Mann-Whitney U=137,50; $P=0.130$, MDA: Malondialdehyde

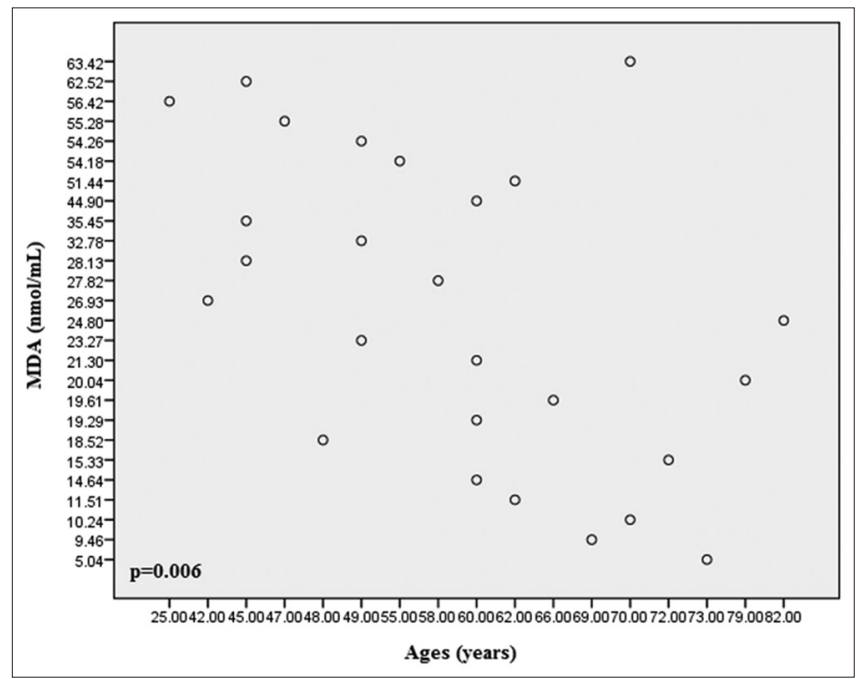

FIGURE 1. Statistically significant correlation between serum malondialdehyde levels and ages of breast cancer patients with positive axillary lymph nodes (Spearman rho $=-0.525, p=0.006$ ).

induces ROS production selectively in ER-positive MCF7 cells (42). In our study, we have not obtained a statistically significant difference in MDA serum levels between ER-positive and ER-negative breast cancer patients (Table 4). A case-control study in a wide population of breast cancer patients including both estrogen positive and estrogen negative cancers showed that oxidative stress parameters were positively associated with breast cancer in a postmenopausal woman with higher body mass index (43). Considering results from previous studies, we have tested differences in MDA serum levels between breast cancer patients regarding menopausal status.
No statistically significant difference in MDA serum level between breast cancer patients with premenopausal status in relation to patients with postmenopausal status (Table 5). Molecular mechanisms that relate oxidative stress and ERs signaling are very complex and including other molecules such as interleukin-8 (IL-8), vascular endothelial growth factor (37), IL-6, or other processes such as inflammation (41). Thus, further investigation of breast cancer biology from the overview of oxidative stress may be helpful in the understanding of breast cancer etiology and may contribute to the development of new approaches to cancer therapy. 
However, we showed statistically significant negative correlation between MDA serum levels in patients with positive lymph nodes and their ages $(p=0.006)$, which is consistent with findings from two relatively large trials that have demonstrated a worse prognosis for patients $<35$ years age, even after adjustment for other prognostic factors $(44,45)$.

In conclusion, obtained results support the importance of MDA in the carcinogenesis of breast cancer, although according to our findings serum level of MDA could not be a useful prognostic factor in breast cancer.

\section{REFERENCES}

1. Sheikhpour R. Evaluation of Tp53 codon 72 polymorphism and resulted protein in breast cancer patients in Yazd city Iran. J Breast Dis 2014;7(3):20-9.

2. Sheikhpour R, Mohiti J. The effect of progesterone on $p 53$ in T47D cell line. Urmia J Med Sci 2014;25(10):954-60.

3. Rockenbach G, Di Pietro PF, Ambrosi C, Boaventura BC, Vieira FG, Crippa CG, et al. Dietary intake and oxidative stress in breast cancer: Before and after treatments. Nutr Hosp 2011;26(4):737-44.

4. Halliwell B, Gutteridge JM. Free Radicals in Biology and Medicine. $4^{\text {th }}$ ed. New York: Oxford University; 2007

5. Pani G, Giannoni E, Galeotti T, Chiarugi P. Redox-based escape mechanism from death: The cancer lesson. Antioxid Redox Signal 2009;11(11):2791-806.

https://doi.org/10.1089/ars.2009.2739.

6. Mannello F, Tonti GA, Medda V. Protein oxidation in breast microenvironment: Nipple aspirate fluid collected from breast cancer women contains increased protein carbonyl concentration. Cell Oncol 2009;31:383-92.

7. Gago-Dominguez M, Jiang X, Castelao JE. Lipid peroxidation, oxidative stress genes and dietary factors in breast cancer protection: A hypothesis. Breast Cancer Res 2007;9:201. https://doi.org/10.1186/bcr1628.

8. Gago-Dominguez M, Jiang X, Esteban Castelao J. Lipid peroxidation and the protective effect of physical exercise on breast cancer. Med Hypotheses 2007;68:1138-43.

https://doi.org/10.1016/j.mehy.2006.09.026.

9. Brown NS, Bicknell R. Hypoxia and oxidative stress in breast cancer. Oxidative stress: Its effects on the growth, metastatic potential and response to therapy of breast cancer. Breast Cancer Res 2001;3:323-7. https://doi.org/10.1186/bcr315.

10. Wiseman $\mathrm{H}$, Halliwell B. Damage to DNA by reactive oxygen and nitrogen species: Role in inflammatory disease and progression to cancer. Biochem J 1996;313(Pt 1):17-29.

https://doi.org/10.1042/bj3130017.

11. Szatrowski TP, Nathan CF. Production of large amounts of hydrogen peroxide by human tumor cells. Cancer Res 1991;51:794-8.

12. Burdon RH. Superoxide and hydrogen peroxide in relation to mammalian cell proliferation. Free Radic Biol Med 1995;18:775-94.

https://doi.org/10.1016/0891-5849(94)00198-S.

13. Brown NS, Jones A, Fujiyama C, Harris AL, Bicknell R. Thymidine phosphorylase induces carcinoma cell oxidative stress and promotes secretion of angiogenic factors. Cancer Res 2000;60:6298-302.
14. Wang X, Martindale JL, Liu Y, Holbrook NJ. The cellular response to oxidative stress: Influences of mitogen-activated protein kinase signalling pathways on cell survival. Biochem J 1998;333(Pt 2):291-300.

https://doi.org/10.1042/bj3330291.

15. Lykkesfeldt J. Malondialdehyde as biomarker of oxidative damage to lipids caused by smoking. Clin Chim Acta 2007;380:50-8.

https://doi.org/10.1016/j.cca.2007.01.028.

16. Tavassoli FA, Devilee $P$, editors. Tumours of the breast. In: Classification of Tumours. Pathology and Genetics of Tumours of the Breast and Female Genital Organs. Lyon: IARC Press, World Health Organisation; 2003. p. 9-110.

17. Remmele W, Stegner HE. Recommendation for uniform definition of an immunoreactive score (IRS) for immunohistochemical estrogen receptor detection (ER-ICA) in breast cancer tissue. Pathologe 1987;8:138-40.

18. Halliwell B, Chirico S. Lipid peroxidation: Its mechanism, measurement, and significance. Am J Clin Nutr 1993;57:715S-24.

https://doi.org/10.1093/ajcn/57.5.715S.

19. Conti M, Morand PC, Levillain P, Lemonnier A. Improved fluorometric determination of malonaldehyde. Clin Chem 1991;37(7):1273-5.

20. Lykkesfeldt J. Determination of malondialdehyde as dithiobarbituric acid adduct in biological samples by HPLC with fluorescence detection: Comparison with ultraviolet-visible spectrophotometry. Clin Chem 2001;47(9):1725-7.

21. Del Rio D, Pellegrini N, Colombi B, Bianchi M, Serafini M, Torta F, et al. Rapid fluorimetric method to detect total plasma malondialdehyde with mild derivatization conditions. Clin Chem 2003;49(4):690-2.

https://doi.org/10.1373/49.4.690.

22. Grintzalis K, Zisimopoulos D, Grune T, Weber D, Georgiou CD. Method for the simultaneous determination of free/protein malondialdehyde and lipid/ protein hydroperoxides. Free Radic Biol Med 2013;59:27-35.

https://doi.org/10.1016/j.freeradbiomed.2012.09.038.

23. Wasowicz W, Nève J, Peretz A. Optimized steps in fluorometric determination of thiobarbituric acid-reactive substances in serum: Importance of extraction $\mathrm{pH}$ and influence of sample preservation and storage. Clin Chem 1993;39(12):2522-6.

24. Yagi K. Simple assay for the level of total lipid peroxides in serum or plasma. Methods Mol Biol 1998;108:101-6.

https://doi.org/10.1385/0-89603-472-0:101.

25. Sahu A, Varma M, Kachhawa K. A prognostic study od MDA, SOD and catalase in breast cancer patients. Int J Sci Res 2013;4(5):157-9.

26. Didžiapetrienè J, Bublevič J, Smailytè G, Kazbarienė B, Stukas R. Significance of blood serum catalase activity and malondialdehyde leve for survival prognosis of ovarian cancer patients. Medicina (Kaunas) 2014;50:204-8.

https://doi.org/10.1016/j.medici.2014.09.001.

27. Sadati Zarrini A, Moslemi D, Parsian H, Vessal M, Mosapour A, Shirkhani Kelagari Z, et al. The status of antioxidants, malondialdehyde and some trace elements in serum of patients with breast cancer. Caspian J Intern Med 2016;7(1):31-6.

28. Bakan E, Taysi S, Polat MF, Dalga S, Umudum Z, Bakan N, et al. Nitric oxide levels and lipid peroxidation in plasma of patients with gastric cancer. Jpn J Clin Oncol 2002;32:162-6. https://doi.org/10.1093/jjco/hyf035.

29. Gupta A, Srivastava S, Prasad R, Natu SM, Mittal B, Negi MP, et al. Oxidative stress in non-small cell lung cancer patients after chemotherapy: Association with treatment response. Respirology 2010;15:349-56. https://doi.org/10.1111/j.1440-1843.2009.01703.x.

30. Chole RH, Patil RN, Basak A, Palandurkar K, Bhowate R. Estimation of serum malondialdehyde in oral cancer and precancer and its association with healthy individuals, gender, alcohol, and tobacco abuse. J Cancer Res 


\section{Ther 2010;6:487-91.}

https://doi.org/10.4103/0973-1482.77106.

31. Gönenç A, Erten D, Aslan S, Akinci M, Simşek B, Torun M, et al. Lipid peroxidation and antioxidant status in blood and tissue of malignant breast tumor and benign breast disease. Cell Biol Int 2006;30:376-80.

https://doi.org/10.1016/j.cellbi.2006.02.005.

32. Sener DE, Gönenç A, Akinci M, Torun M. Lipid peroxidation and total antioxidant status in patients with breast cancer. Cell Biochem Funct 2007;25:377-82. https://doi.org/10.1002/cbf.1308.

33. Qebesy HS, Zakhary MM, Abd-Aaziz MA, Ghany AA, Maximus DW. Tissue levels of oxidatibe stress markers and antioxidants in breast cancer patients in relation to tumor grade. Al-Azhar Assuit Med J 2015;13(4):10-6.

34. Page DL. Adenoid cystic carcinoma of breast, a special histopathologic type with excellent prognosis. Breast Cancer Res Treat 2005;93:189-90. https://doi.org/10.1007/s10549-005-5198-3.

35. Cianfrocca M, Goldstein LJ. Prognostic and predictive factors in early-stage breast cancer. Oncologist 2004;9:606-16. https://doi.org/10.1634/theoncologist.9-6-606.

36. Saez RA, McGuire WL, Clark GM. Prognostic factors in breast cancer. Semin Surg Oncol 1989;5:102-10. https://doi.org/10.1002/ssu.2980050206.

37. Thyagarajan A, Jiang J, Hopf A, Adamec J, Sliva D. Inhibition of oxidative stress-induced invasiveness of cancer cells by Ganoderma lucidum is mediated through the suppression of interleukin-8 secretion. Int J Mol Med 2006;18(4):657-64. https://doi.org/10.3892/ijmm.18.4.657.

38. Hilsenbeck SG, Ravdin PM, de Moor CA, Chamness GC, Osborne CK, Clark GM, et al. Time-dependence of hazard ratios for prognostic factors in primary breast cancer. Breast Cancer Res Treat 1998;52:227-37. https://doi.org/10.1023/A:1006133418245.

39. Hursting SD, Berger NA. Energy balance, host-related factors, and cancer progression. J Clin Oncol 2010;28:4058-65.

https://doi.org/10.1200/JCO.2010.27.9935.

40. Acharya A, Das I, Chandhok D, Saha T. Redox regulation in cancer: A double-edged sword with therapeutic potential. Oxid Med Cell Longev 2010;3:23-34.

https://doi.org/10.4161/oxim.3.1.10095.

41. Madeddu C, Gramignano G, Floris C, Murenu G, Sollai G, Macciò A, et al. Role of inflammation and oxidative stress in post-menopausal oestrogen-dependent breast cancer. J Cell Mol Med 2014;18(12):2519-29. https://doi.org/10.1111/jcmm.12413.

42. Mobley JA, Brueggemeier RW. Estrogen receptor-mediated regulation of oxidative stress and DNA damage in breast cancer. Carcinogenesis 2004;25(1):3-9. https://doi.org/10.1093/carcin/bgg175.

43. Dai Q, Gao YT, Shu XO, Yang G, Milne G, Cai Q, et al. Oxidative stress, obesity, and breast cancer risk: Results from the shanghai women's health study. J Clin Oncol 2009;27:2482-8.

https://doi.org/10.1200/JCO.2008.19.7970.

44. Nixon AJ, Neuberg D, Hayes DF, Gelman R, Connolly JL, Schnitt S, et al. Relationship of patient age to pathologic features of the tumor and prognosis for patients with stage I or II breast cancer. J Clin Oncol 1994;12:888-94. https://doi.org/10.1200/JCO.1994.12.5.888.

45. Albain KS, Allred DC, Clark GM. Breast cancer outcome and predictors of outcome: Are there age differentials? J Natl Cancer Inst Monogr 1994;16:35-42. 